\title{
NATURAL AND ANTHROPOGENIC IMPACT ON THE FORMATION OF ARCHAEOLOGICAL LAYERS IN A LAKE-SHORE AREA: CASE STUDY FROM THE SERTEYA II SITE, WESTERN RUSSIA
}

\author{
ANDREY MAZURKEVICH ${ }^{1}$, PIOTR KITTEL ${ }^{2}$, YOLAINE MAIGROT ${ }^{3}$, \\ EKATERINA DOLBUNOVA ${ }^{1}$, AGNIESZKA MROCZKOWSKA ${ }^{2,4}$, \\ MAGDA WIECKOWSKA-LÜTH ${ }^{5}$, WIKTOR PIECH ${ }^{2}$
}

\begin{abstract}
The article presents the results of a study on archaeological structures and horizons developed in the palaeolake shore-zone of the Serteya II site that was occupied intermittently and to a greater or lesser intensity from the Mesolithic up to the Middle Ages. The Serteya II site is a multilayer complex used by hunter-fisher-gatherer communities in the $9^{\text {th }}-8^{\text {th }}$ mill. $\mathrm{BC}$, and from the end of the $7^{\text {th }}$ till the end of the $3^{\text {rd }}$ mill. $\mathrm{BC}$. The article is focused on the particularities of the formation of archaeological layers and the reconstruction of the ancient environment in different periods of time. The study of the sets of artefacts, their state of preservation, as well as the traits of archaeological features, may indicate the peculiarities of the formation of different sedimentological units. Based on the results of complex natural-scientific research it was possible to reconstruct the palaeo-ecology of changing water regimes as well as changes in environmental conditions.
\end{abstract}

Key words: archaeological layers, pile-dwellings, palaeoecology, hunter-fisher-gatherers, Neolithic, Eneolithic

\section{Introduction}

The Serteya II site located in the DneprDvina basin (Western Russia) (Fig. 1) is an archaeological multi-layered complex with remnants from the Mesolithic up to the Middle Ages. It was divided into the following sectors: Serteya II-1 (the eastern section on the right bank of the Serteyka river) and Serteya IIsub (the underwater section, adjacent to the eastern part and located in the channel of the Serteyka river) - with the remnants of a pile-dwelling; Serteya II-2 (the western part in the peat bog and palaeolake basin); and Serteya II layer $a$ (located on a kame terrace and directly adjacent to Serteya II-2) (Fig. 1). In the eastern core zone (Sert- eya II-1 and sub) of the settlement area, several pile-dwellings existed, mostly during ca 29002000 cal. BC (Table 1, 2, 3). They are located within the deep water of the palaeolake basin (Kittel et al. 2018). The western part of the site (Serteya II-2), situated in the palaeolake shore area, has a more complex archaeological stratigraphy due to the different periods of inhabitation (Mazurkevich et al. 2017a, b; Kittel et al. 2020a). The geomorphological situation of this part is also more complex (see Kittel et al. 2020b). Numerous features, artefacts and ecofacts were documented within layers of coarsedetritus gyttja and underlying sands with organic mud admixtures, as well as within silty-sand deposits of the shore zone.

\footnotetext{
${ }^{1}$ The State Hermitage Museum, Department of Archaeology of Eastern Europe and Siberia, Dvortsovaya Naberezhnaya 34, 190000 Saint Petersburg, Russia; e-mail: a-mazurkevich@mail.ru, ORCID: 0000-0002-4947-0498; katjer@mail.ru, ORCID: 0000-0003-1843-9620

${ }^{2}$ University of Lodz, Faculty of Geographical Sciences, Department of Geology and Geomorphology, ul. Narutowicza 88, 90-139 Łódź, Poland; e-mail: piotr.kittel@geo.uni.lodz.pl, ORCID: 0000-0001-6987-7968; piechwiktor@gmail.com, ORCID: 0000-0001-5068-1631

3 UMR 8215 Trajectoires, CNRS-Université Paris 1 Panthéon - Sorbonne, Nanterre, France; e-mail: Yolaine. MAIGROT@cnrs.fr, ORCID 0000-0001-5636-3685

${ }^{4}$ Polish Academy of Sciences, Institute of Geography and Spatial Organization, ul. Twarda 51/55, 00-818 Warsaw, Poland; e-mail: A Mroczkowska@outlook.com, ORCID: 0000-0002-3534-7843

${ }^{5}$ University of Kiel, Institute of Prehistoric and Protohistoric Archaeology, Archaeobotanical and Palynological Laboratory, Germany; e-mail: mwieckowska@ufg.uni-kiel.de, ORCID: 0000-0002-1940-6700
} 


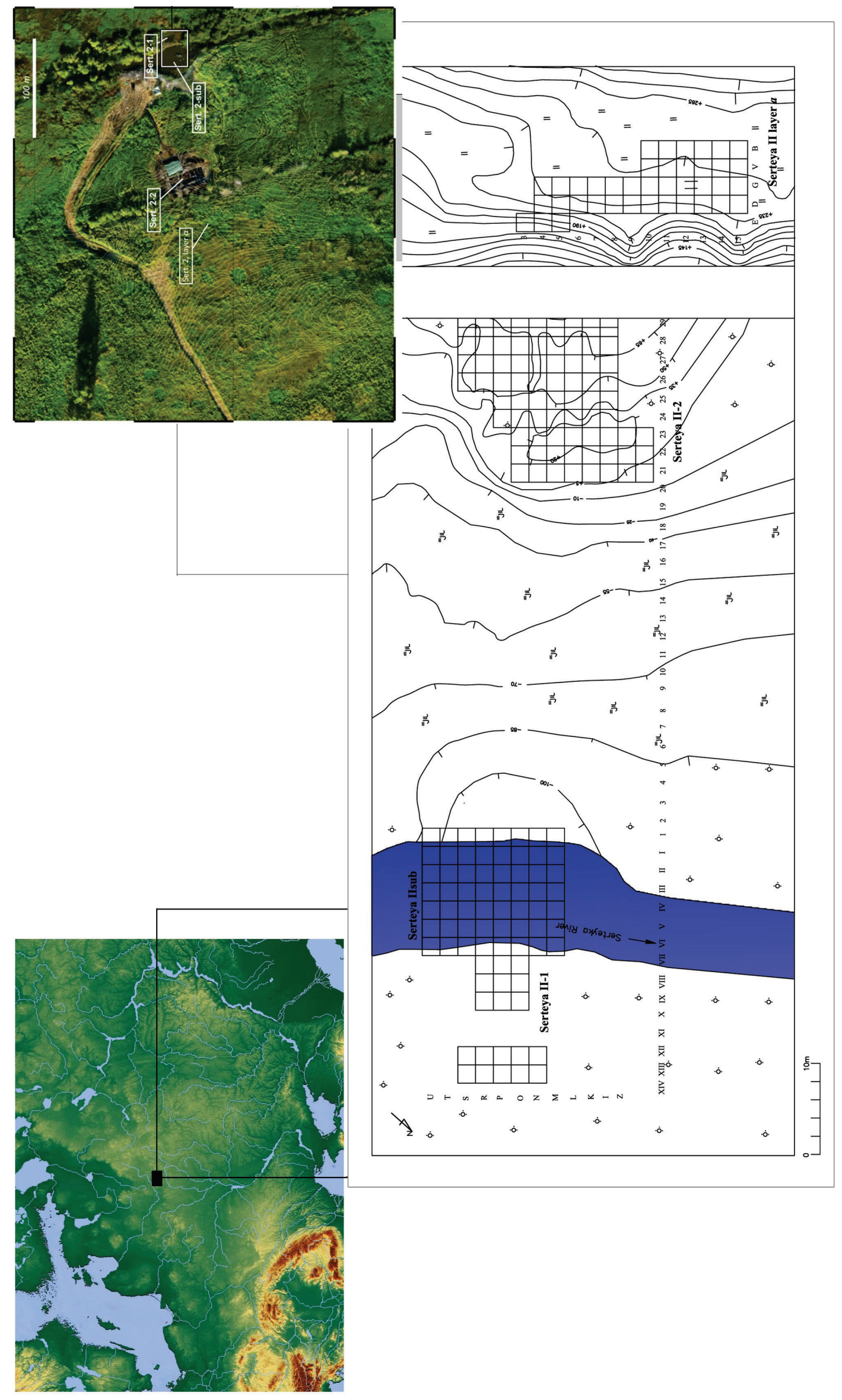

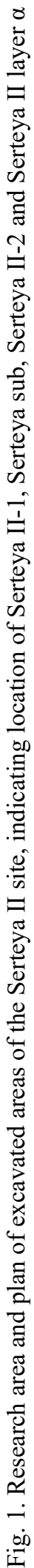


Radiocarbon date set of the pile-dwelling construction 1/6 (Serteya IIsub)

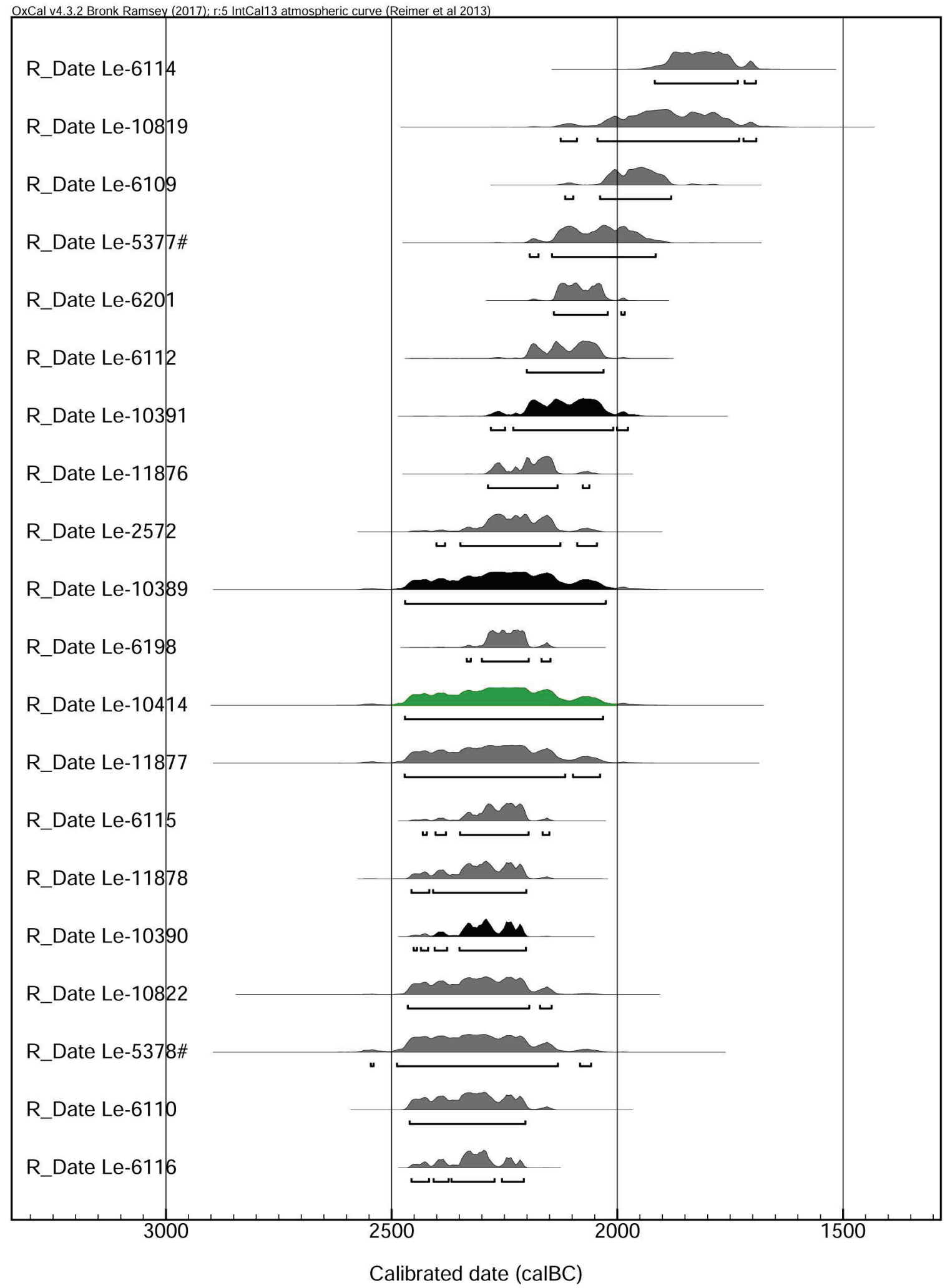




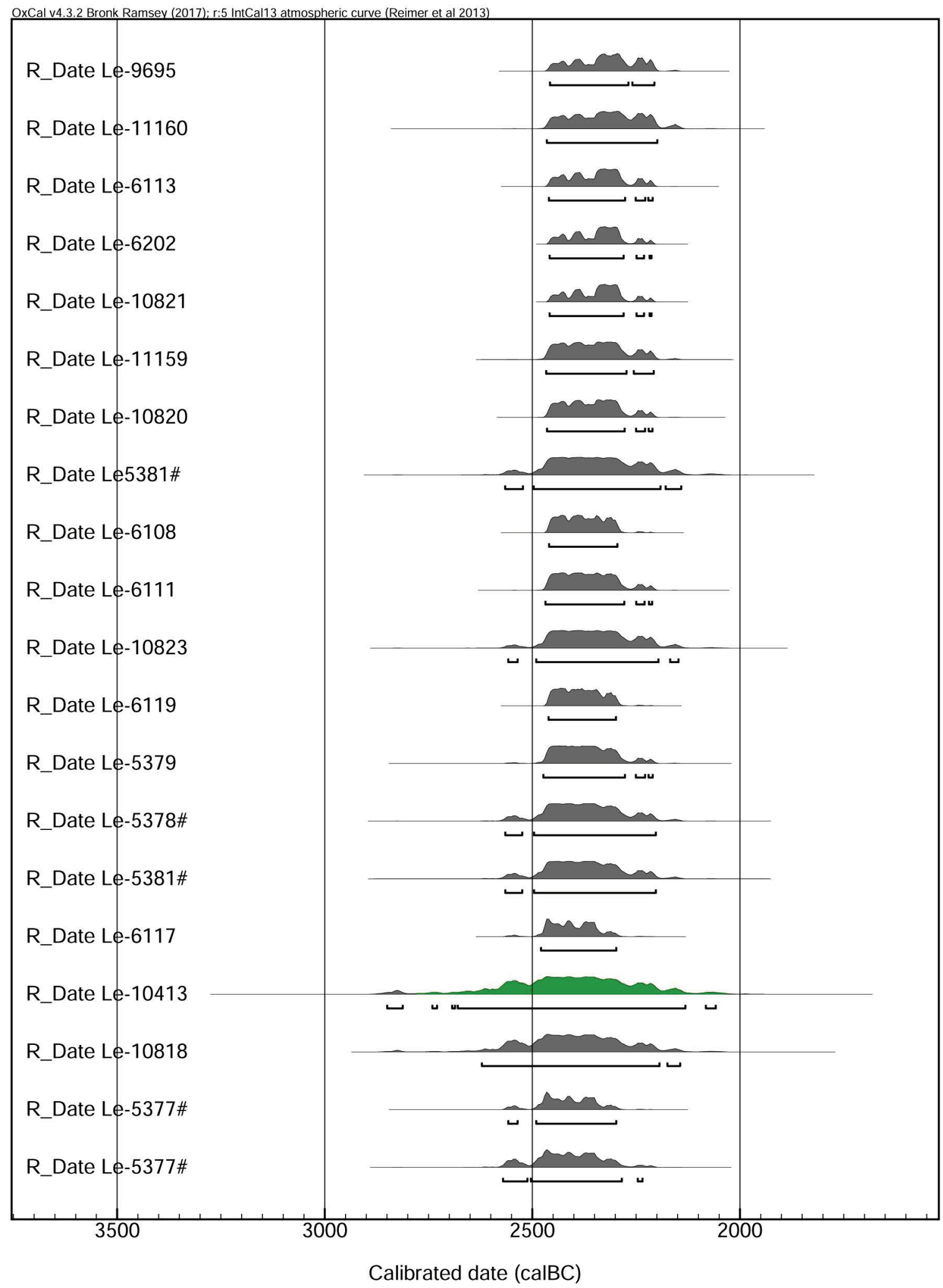




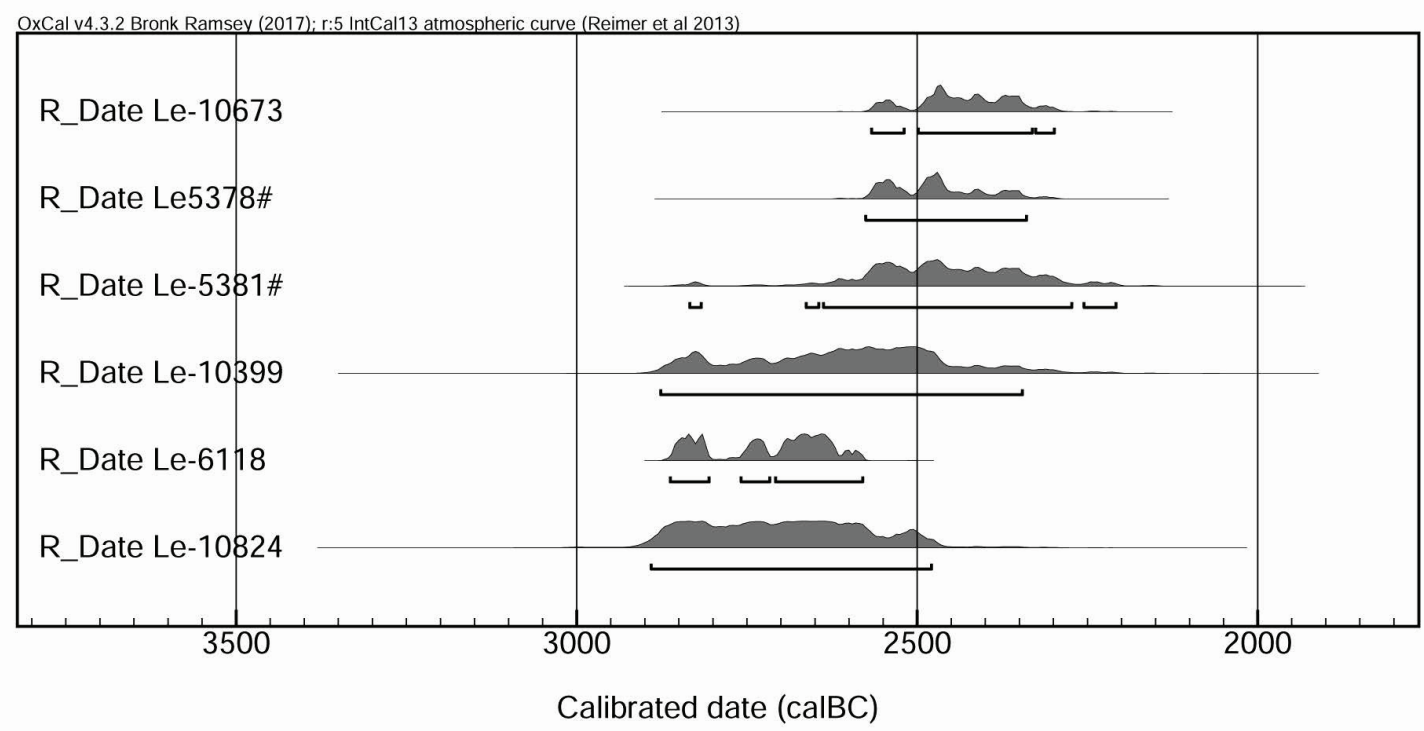

grey - wooden piles and parts of the pile-dwelling, black - charcoal, green - bone

Table 2

Radiocarbon date set of pile-dwelling construction 2 (Serteya IIsub)

(wooden elements of the construction were dated)

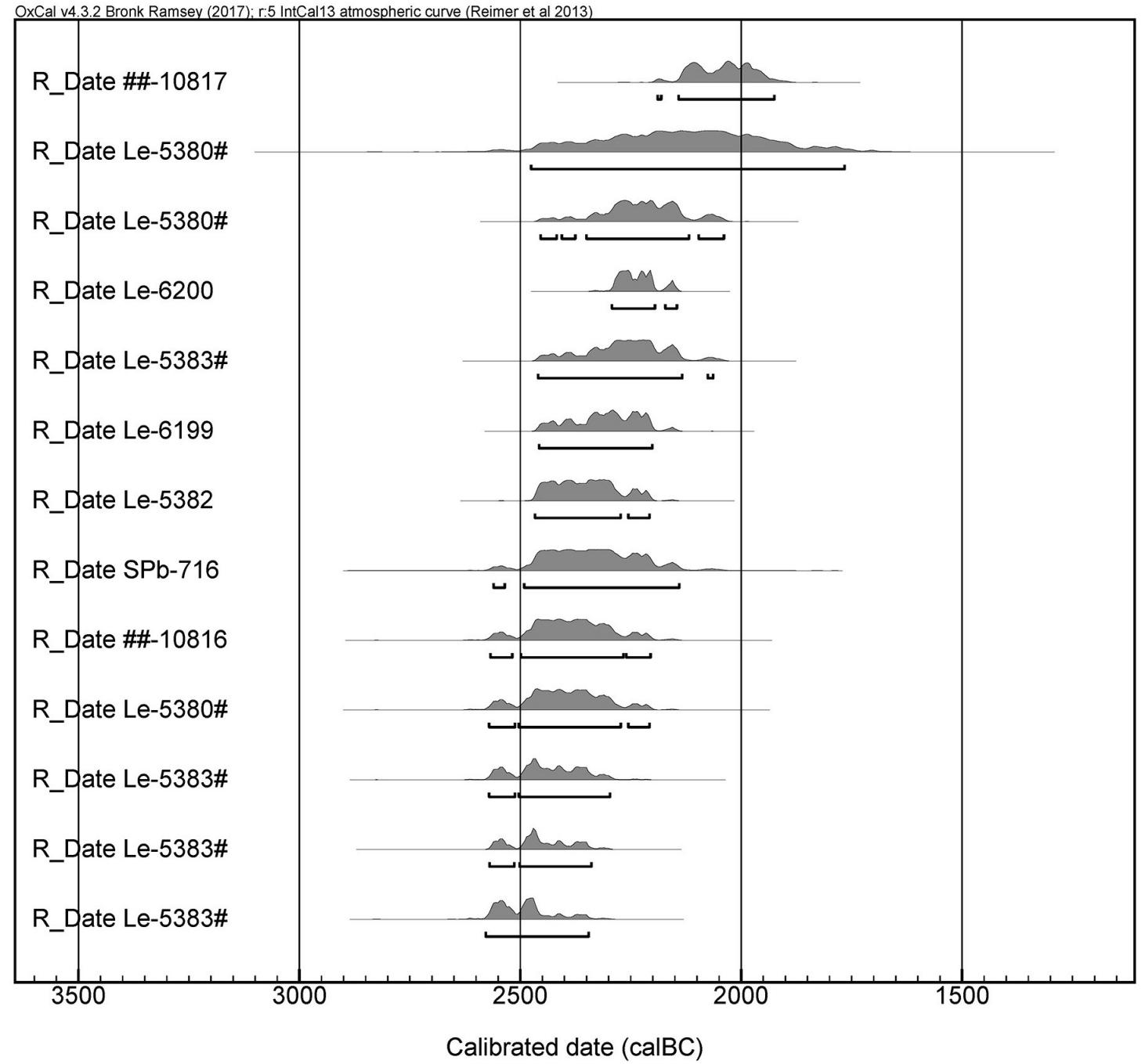


Table 3

Radiocarbon date set of pile-dwelling construction 3 (Serteya IIsub and Serteya II-1) (wooden elements of the construction were dated)

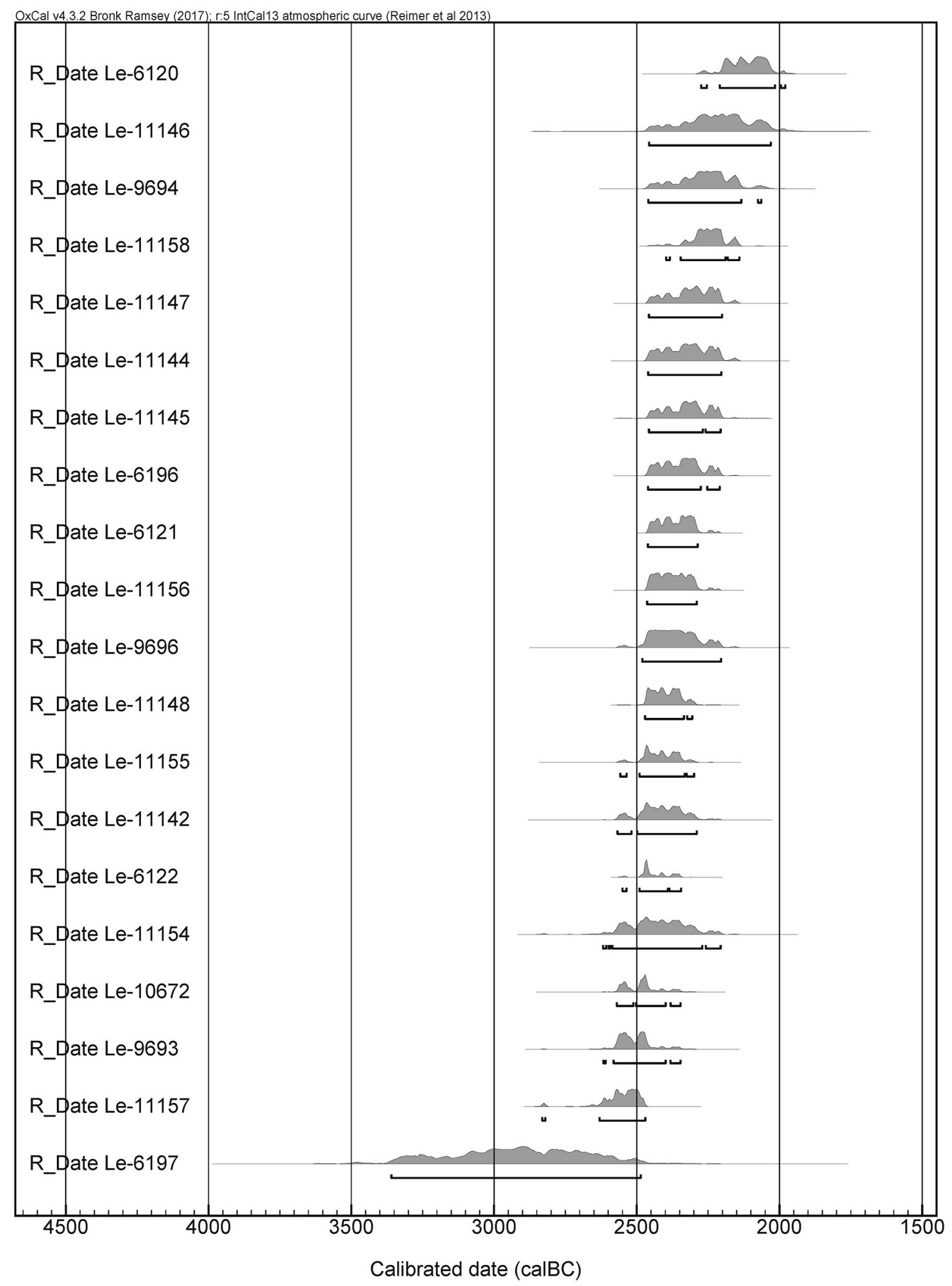


Given the different origin of the lithological layers' formation and differences in the process of deposition of cultural remains, the latter were influenced by different taphonomical processes. This affected the preservation state of artefacts and ecofacts in different areas of the site, as well as their quantity and particular groups (e.g. zones with scattered pottery fragments, paddles, elements of constructions, etc.). In the past, this area was either a shore zone of a palaeolake, a swamp, or a flooded area. This led to various economic activities, e.g. constructions related to lake fishing and various dwellings and household structures, etc. In turn, this affected the formation of contexts and the composition of the artefact categories.

The exceptional importance of the palaeoecological reconstruction of the local environment concerns the palaeohydrological conditions (water level fluctuations) of the Great Serteya Palaeolake Basin (GSPB) where the Serteya II site is located. The palaeohydrological conditions, the palaeolake evolution and the fluvial regime of the Serteyka River were the forces driving water table fluctuations, and determined the development of the settlement pattern there. This study is focused on the Holocene history of various deposits and features developed in the palaeolake shore zone under the influence of palaeoenvironmental changes and the episodic impact of small human groups. In this article, we try to change the emphasis of the research object usually applied for archaeological remains. Traditionally, the main object of research is the human being, the remnants of human life activity and related historical processes. Here we propose to focus on the particularities of the formation of archaeological layers, and on the reconstruction of the ancient environment in different periods of time by studying sets of artefacts and their preservation, as well as archaeological structures that may indicate the peculiarities of the formation of different sediments, changing water regimes and changes in the environment along with complex natural-scientific research.

\section{Cultural timeframe of the Serteya II site}

For different areas of Eastern Europe, the time span of the Neolithic and Eneolithic are dated differently. The Early Neolithic is dated from the $6^{\text {th }}$ to the beginning of the $5^{\text {th }}$ mill. BC in some parts of the forest zone of Eastern Europe, whereas the Eneolithic cultures in the southern part of Eastern Europe are also dated to the $6^{\text {th }}-5^{\text {th }}$ mill. BC based on radiocarbon dates (Chernykh et al. 2000; Morgunova et al. 2010; Mazurkevich et al. 2016). In the steppe zone, the change in cultural pattern was more dynamic in this period. In the forest zone, cultures retarding can be traced, as well as an absence of the main features of these epochs, e.g. indications of productive economies for the Neolithic, and copper items for the Eneolithic.

Such a paradoxical situation can be suggested for the Dnepr-Dvina region, where Early Neolithic groups were succeeded by Eneolithic cultures who were in turn followed by Middle and Late Neolithic cultures, as proposed based on the archaeological classification established for the forest zone. Materials recently found here evidence a penetration of Eneolithic cultures from the forest-steppe and steppe areas in the Dnepr-Dvina region in the $5^{\text {th }}-4^{\text {th }}$ mill. BC. A complete change in ceramic traditions, the appearance of new ornaments (Fig. 2) and specific flint arrowheads all seem to indicate direct migrations into this area.

The penetration of other social groups to this region did not lead to any major changes in the economic system of the local groups, either during this period of time or later. This led to the formation of similar archaeological contexts traced at Serteya II site: a hunting place, fishing place, dwelling area and butchering area, with the remnants of hunter-gatherer communities' way of life sustained for several millennia. However, significant changes in the material culture and imported items (e.g. imported vessels attested by petrographic and geochemical analysis - Fig. 3-1 [see Mazurkevich et al. 2014]) might evidence very intense cultural relations. In order to highlight this, the term "Forest Neolithic" is applied to local cultures whose subsistence economy was based on hunting and gathering but who were simultaneously significantly influenced by societies with productive economies that might have changed their way of life. The Middle Forest Neolithic is represented by materials of the Usviaty Culture (3100-2900 BC). The Late Forest Neolithic is represented by the Zhizhitsa Culture (3000-2300/2000 BC). The latter was influenced by the Globular Amphora Culture (Fig. 3) (Miklyaev 1995; Szmyt 2010), and some similarities with the Rzucewo Culture may be suggested (Zaltsman 2019). 


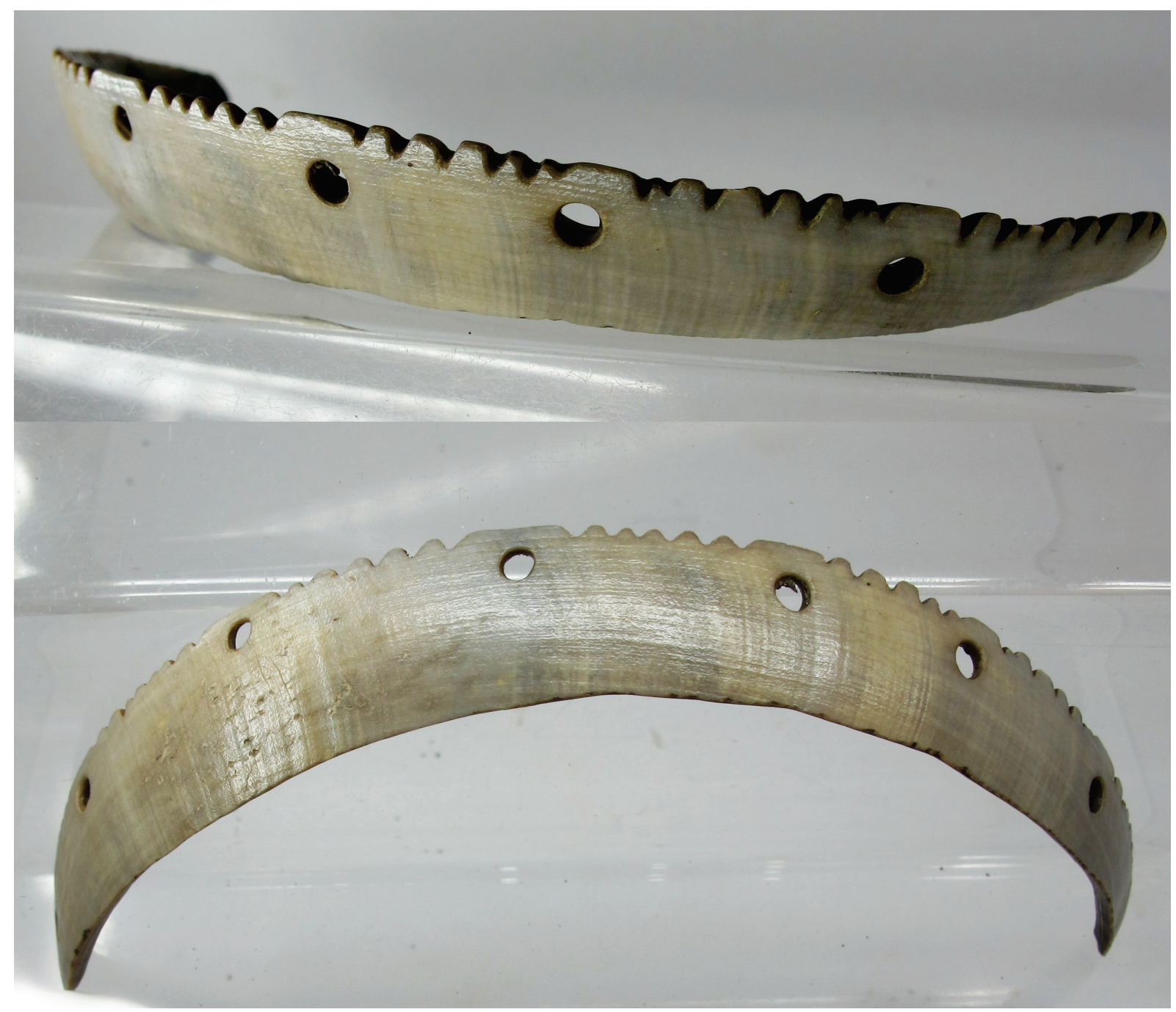

Fig. 2. Pendant made from boar tusk attributed to the Eneolithic (Serteya II-2)

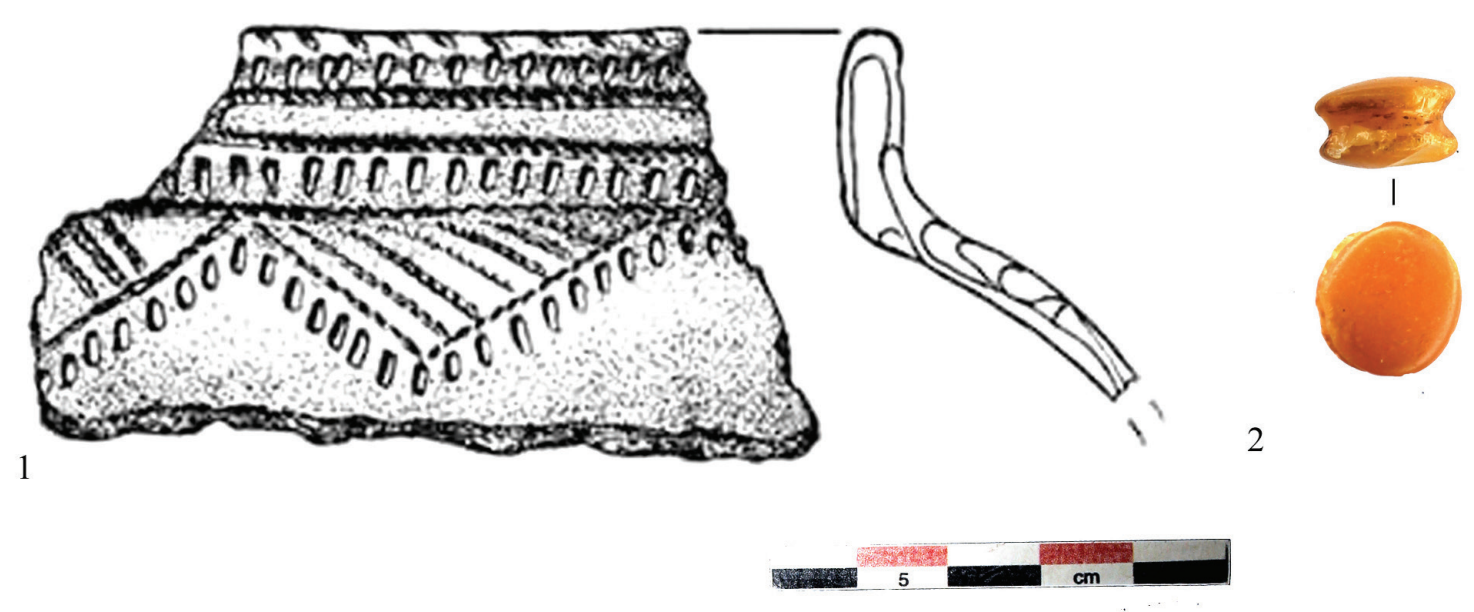

Fig. 3. Amber pendant (2) and "imported" vessel (1) - traces of Globular Amphora Culture influence (Serteya IIsub) 


\section{Material and methods}

The western shore zone part of the Serteya II site was excavated from 2015 onwards using wetland archaeological methods (Fig. 4). The eastern part of the site has been excavated with underwater and wetland archaeological methods since 1972. The precise location of all finds was threedimensionally recorded with the use of a laser tachymeter. Traits, stratigraphy, microstratigraphy and relationships of anthropogenic and natural sediments were observed in the field and registered. Typological-chronological analyses of artefacts and ecofacts along with their 3D distribution and ${ }^{14} \mathrm{C}$ dating are regarded to be an important proxy for interpreting the periodisation, the natural and artificial conditions, the formation of archaeological layers and the depositional units.

Several cores were taken from the site for multiproxy palaeoecological analyses (see Kittel et al. 2020a, b). The detailed palaeoecological reconstructions for the western part of the Serteya II site were obtained based on the study of the STII (Serteya II) M25 core of organic deposits collected in the M/25 square of the Serteya II-2 part of the site and was described by Kittel et al. (2020a). Based on the results of the multiproxy palaeoecological analyses of the STII M25 core's deposits, natural environment changes and the human-environment relationships for the period between $c a 4300$ and $c a 1600$ cal. BC were reconstructed. The shore processes and depositional conditions are presented by Kittel et al. (2020b).

Radiocarbon dates were made for wooden elements of pile-dwellings, parts of wooden fishing constructions, charcoal, bones and food crust, with a clear attribution and position of each dated material (see Mazurkevich et al. 2016). Recently achieved AMS radiocarbon dates were made in Poznań Radiocarbon Laboratory (Poz-index). Radiocarbon dates were calibrated based on data (Reimer et al. 2009) using OxCal v4.3.2 Bronk Ramsey (2017).

\section{Results: site stratigraphy}

The stratigraphies of Serteya II-1, II-2, layer $\alpha$ and even on various parts within the II- 2 area differ significantly and reflect the various conditions under which the layers were formed (see more detailed in Kittel et al. 2020a, b).

The stratigraphy of Serteya II-1 comprises a peaty organic mud layer, below - coarse detritus brown gyttja, brownish gyttja with wooden remains and brown sandy gyttja $c a 1.1-1.5 \mathrm{~m}$ b.g.l. with archaeological remains, deposited on muddy lacustrine sediments (Fig. 5).

The Serteya II-2 area has a more complex archaeological stratigraphy due to its location in the palaeolake shore area and the repeated periods of inhabitation, which are the result of the zone having been more accessible at various times, in contrast to the Serteya II-1 area, which was accessible only during a definite period of time. The bottommost sediments of the southern upper shore part of this area (Fig. 6-1) (corresponds to the location of the STII L29 core [see Kittel et al. 2020b]) are sands with organic mud and plant macro remains (depth from 114 to $c a 100 \mathrm{~cm}$ b.g.l.). Above, at a depth between $c a 100$ and $83 \mathrm{~cm}$ b.g.l. muddy sand with organic matter was identified, which passes gradually upward into silty organic mud (ca $83-c a 70 \mathrm{~cm}$ b.g.l.). The uppermost part of the profile is formed by peaty organic mud. The northern part of the Serteya II-2 area (Fig. 6-2) (corresponds to the location of the STII M25 core [Kittel et al. 2020a]) comprises an upper stratum that includes peaty organic mud, silty organic mud and silty brownish gyttja, a middle stratum of brown, blackish, olive, and sandy coarse detritus gyttja layers deposited on a sandy layer (Fig. 6-2).

\section{Results: occupation phases}

\section{Sandy layer with organic mud and clay admixtures (II-2): the earliest occupation phase}

The oldest artefacts are represented by a single find of a Mesolithic bone arrowhead stuck in the lowermost sandy layer. It may have been lost here during hunting. The most ancient group of potsherds is represented by vessel fragments of the Serteya Culture dated to the $7^{\text {th }}-6^{\text {th }}$ mill. BC and the Rudnya Culture (5300-4900 BC) (Mazurkevich, Dolbunova 2015). They were found in sands with organic mud and clay admixtures. Selected plant macrofossils from organic mud lamination were ${ }^{14} \mathrm{C}$ dated to $9647-9334$ cal. BC (Kittel et al. 2018, 2020a). In the shore zone of the GSPB, correlating deposits were accumulated during periodic palaeolake water table fluctuations with inflow of minerogenic material and wave erosion (Kittel et al. 2020b). The found potsherds are eroded and partly rounded, which 


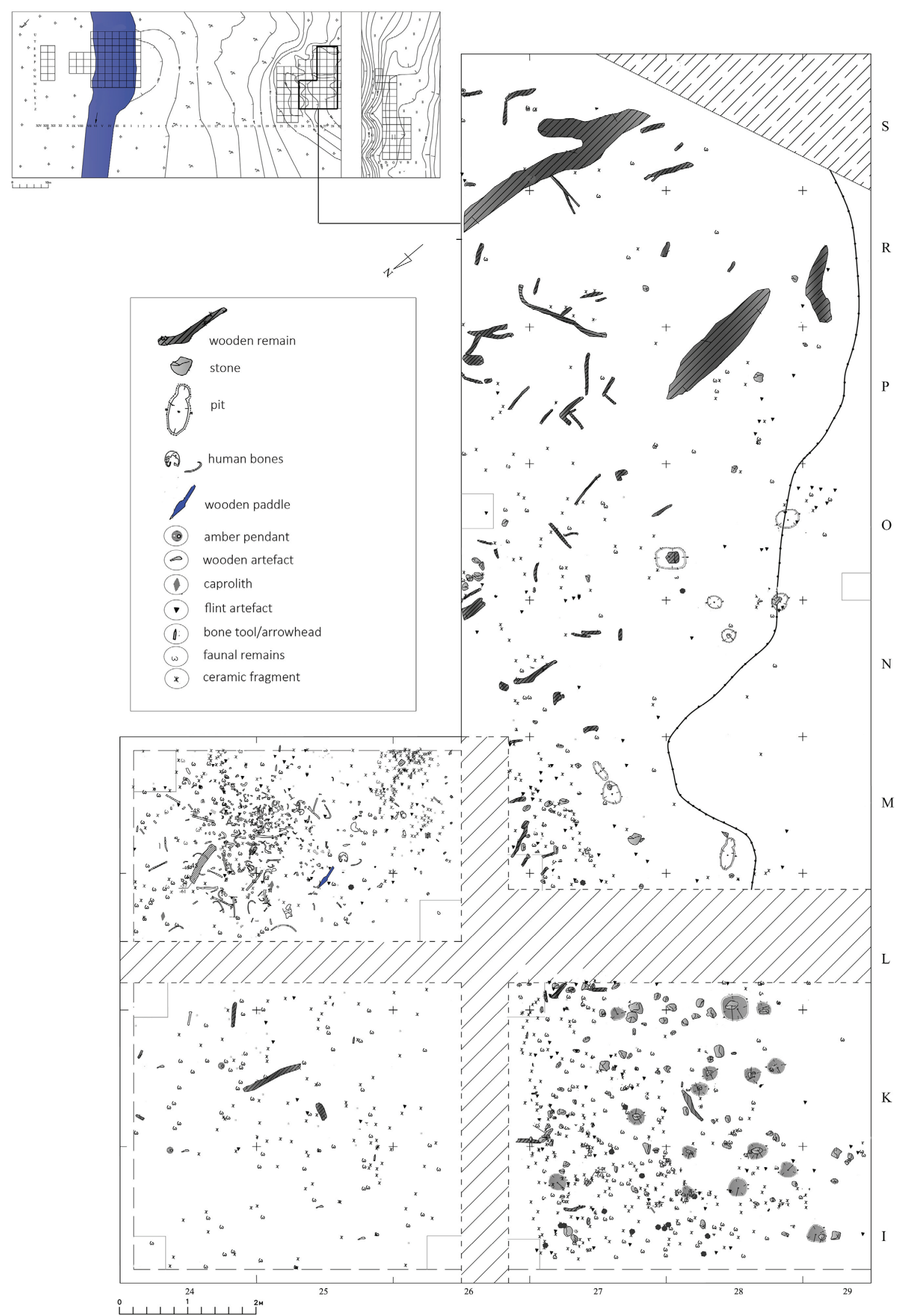

Fig. 4. Brown gyttja with scattered wood, remains of human skeletons, artefacts, pits and stones at the Serteya II-2 site 


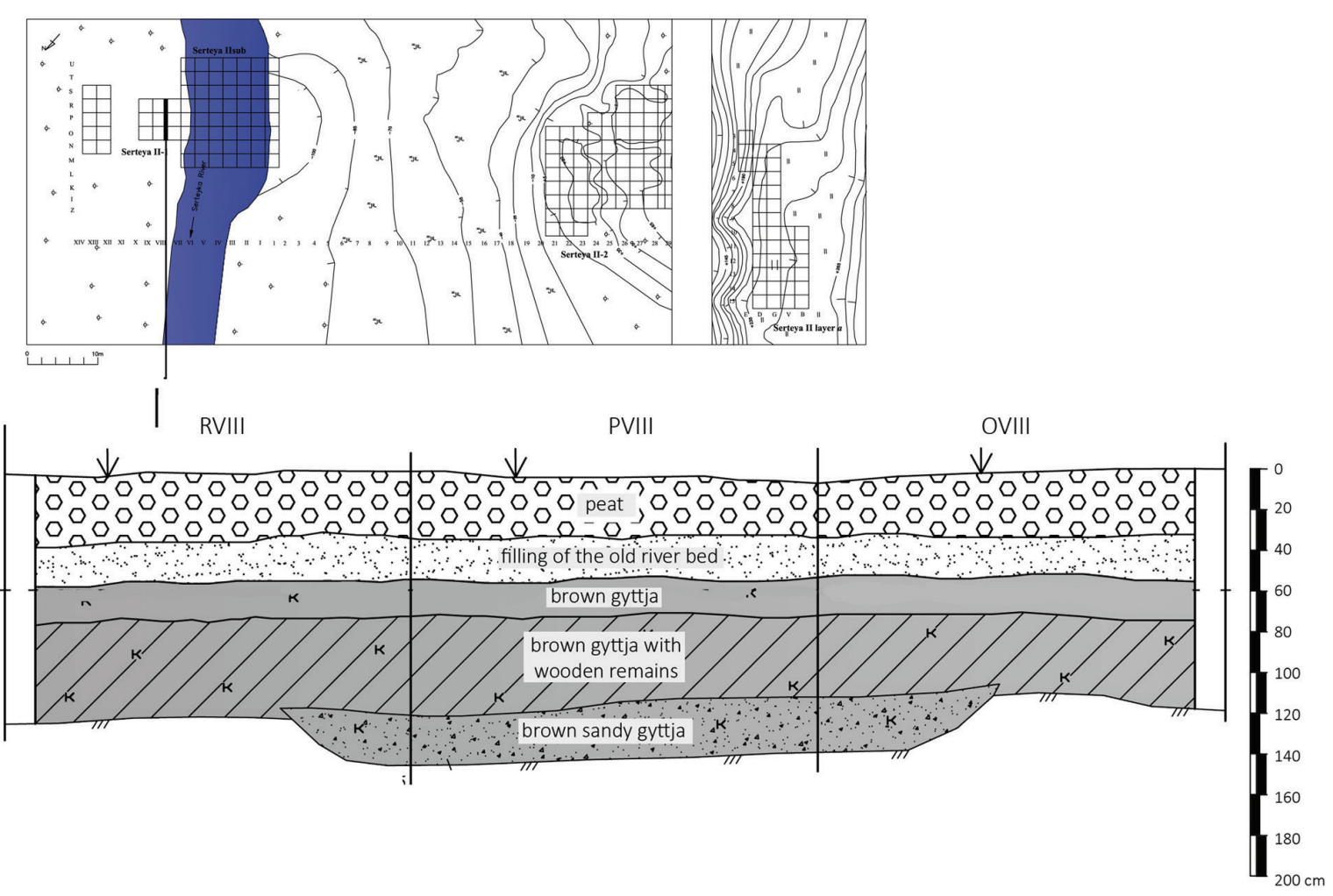

Fig. 5. Stratigraphy of Serteya II-1 area (R-O/VIII profile)

could attest to the redeposition of the archaeological layer and organic matter in the lake shore zone. Fragments of the Rudnya Culture vessels were also found in a lower part of the gyttja layer, which was ${ }^{14} \mathrm{C}$ dated to $4322-4084 \mathrm{cal}$. BC. This suggests that this pottery could have been deposited due to the erosion of the archaeological layer on the sandy slope of a kame of the Serteya II layer $a$ site.

\section{Sandy gyttja layer (II-2) and brownish gyttja layer with wooden remains (II-1): Middle Forest Neolithic (Usviaty Culture)}

The ceramics of the Usvyaty Culture were found in the horizon at a depth of $c a$ 145-147 $\mathrm{cm}$ b.g.l. (in the northern part of the Serteya II-2 area), which corresponds to the upper part of the sandy gyttja layer. It coincides with an increase in charcoal and the horizon of moss (at 140-150 $\mathrm{cm}$ b.g.l.). The youngest fishing construction found at Serteya II-2 area dates to 3086-2896 cal. $\mathrm{BC}$ and might be attributed to the Usviaty Culture. It was deposited during a water level lowering phase with periodic fluctuations (Kittel et al. 2020a).

Rare finds and wooden piles of the second half of the $4^{\text {th }}$ mill. to the turn of the $4^{\text {th }}-3^{\text {rd }}$ mill. BC within the Serteya II-1, -sub areas indicate the location of pile-dwelling structures of the Usvyaty Culture at this place.

\section{Brown and olive coarse-detritus gyttja (II-2, II-1): Eneolithic remains}

In the brown and olive coarse-detritus gyttja at a depth of $c a 120-150 \mathrm{~cm}$ b.g.l., rich Eneolithic cultures remains were recorded $\left(5-4^{\text {th }}\right.$ mill. BC), as well as Middle and Late Forest Neolithic artefacts and ecofacts (from the turn of the $4^{\text {th }}$ $3^{\text {rd }}$ mill. to the $3^{\text {rd }}$ mill. BC). This gyttja layer was dated in the very bottom to $5368 \pm 28 \mathrm{BP}$ (MKL-A3884), i.e. $4322-4084$ cal. BC and from the depth of $116 \mathrm{~cm}$ the date obtained was 3967 33 BP (MKL-A3979), i.e. 2566-2462 cal. BC (Kittel et al. 2020a). 

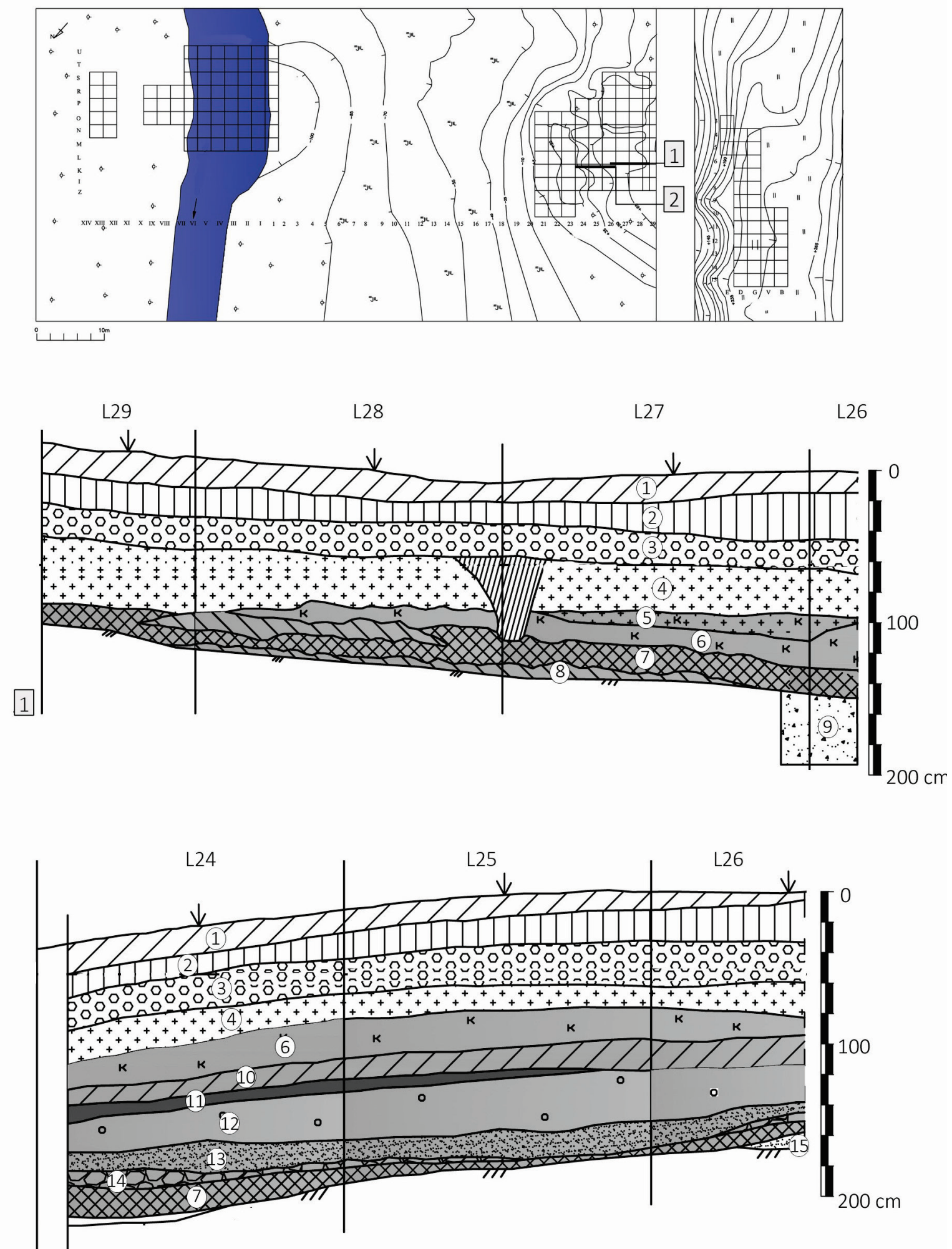

2

Fig. 6. Stratigraphy of Serteya II-2 area

1 - L/29-26 profile; 2 - L/24-26 profile: 1- humic horizon, 2 - dump of the drainage channel, 3 - peaty organic mud, 4 - silty organic mud, 5 - silty brown gyttja, 6 - brown coarse detritus gyttja, 7 - muddy sand with organic matter, 8 - sands with organic mud and plant macro remains, 9 - sandy layer (base layer), 10 - blackish-brown coarse detritus gyttja with wooden remains, 11 - dark brown coarse detritus gyttja, 12 - olive coarse detritus gyttja, 13 - black sandy coarse detritus gyttja, 14 - olive sandy coarse detritus gyttja, 15 - grey sand with clayey particles 
The Eneolithic period encompasses three major cultural episodes and the evidence of various uses of this shore zone. The oldest one is connected with the Khvalynskaya Culture and includes several vessels that were left on an elevated shore zone and deposited in the brown gyttja layer (Fig. 7-1, 8). The gyttja layer that covered them that was dated to the $3^{\text {rd }}$ mill. $\mathrm{BC}$ was washed away, and they were mixed with younger Late Forest Neolithic materials. The next stage is marked by wooden constructions (possibly, fishing constructions) left here dated to 3766-3641 cal. BC, 3633-3372 cal. BC when a water table increase is recorded (Kittel et al. 2020a) (Figs 9, 10). This coincides with the penetration of groups of newcomers from the Middle and Upper Don that is evidenced by single finds of vessels synchronous to one of these constructions (found in Serteya II-1 area, sq. N-S/XII-XIII, Table 4). The last episode is connected with a household area that existed in the shore zone, and that is traced through single finds of wooden paddles, ornaments (Fig. 2) and vessels (Fig. 8). It might be related with the Sredny Stog Culture.
In the eastern (Serteya IIsub, brownish gyttja layer) and the western parts (Serteya II-2, olive gyttja layer) of the site remains of several fishing (?) structures from the end of the $5^{\text {th }}$ mill. $\mathrm{BC}$ and different periods of the $4^{\text {th }}$ mill. BC were found (Table 5). They were left not in the residential area but in the shore zone or under water, precisely dating the episodes of inundation of different parts of the site. The earliest fishing (?) structure found in square $\mathrm{A} / \mathrm{V}$ in the eastern part of the site, about $20 \mathrm{~m}$ from the pile settlement, is dated to $5310 \pm 70$ BP (Le-11875), i.e. 4325-3985 cal. BC. This coincides with the ${ }^{14} \mathrm{C}$ age of $4322-4084 \mathrm{cal}$. $\mathrm{BC}$ obtained for the sample from the very bottom of the gyttja layer $(148 \mathrm{~cm}$ b.g.l. according to the STII M25 core (Kittel et al. 2020a). This data should document the earliest phases of an increase in the palaeolake water level. For before $c a$ 4150 cal. BC, unfavourable conditions for the development of aquatic plant and invertebrates communities were documented (Kittel et al. 2020a).

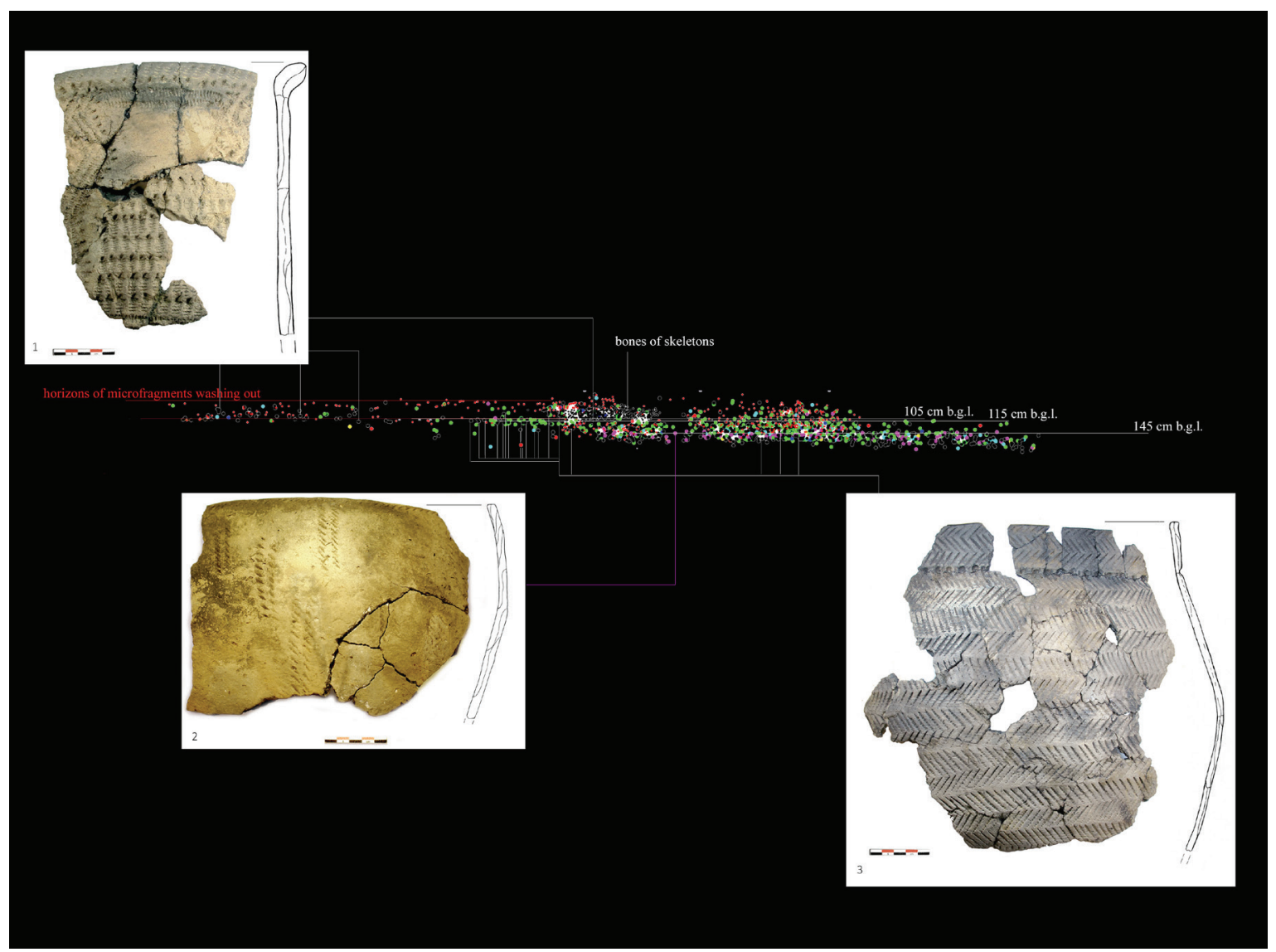

Fig. 7. Reconstruction of different types of vessels distribution

green - Zhizhitsa Culture, black - Eneolithic culture (1,3), magenta - Usviaty Culture (2), blue - Early Neolithic), including micro-fragments (up to $2 \mathrm{~cm}$ - marked by red dots) and remains of human skeletons (marked by black dots) at Serteya II-2 site 

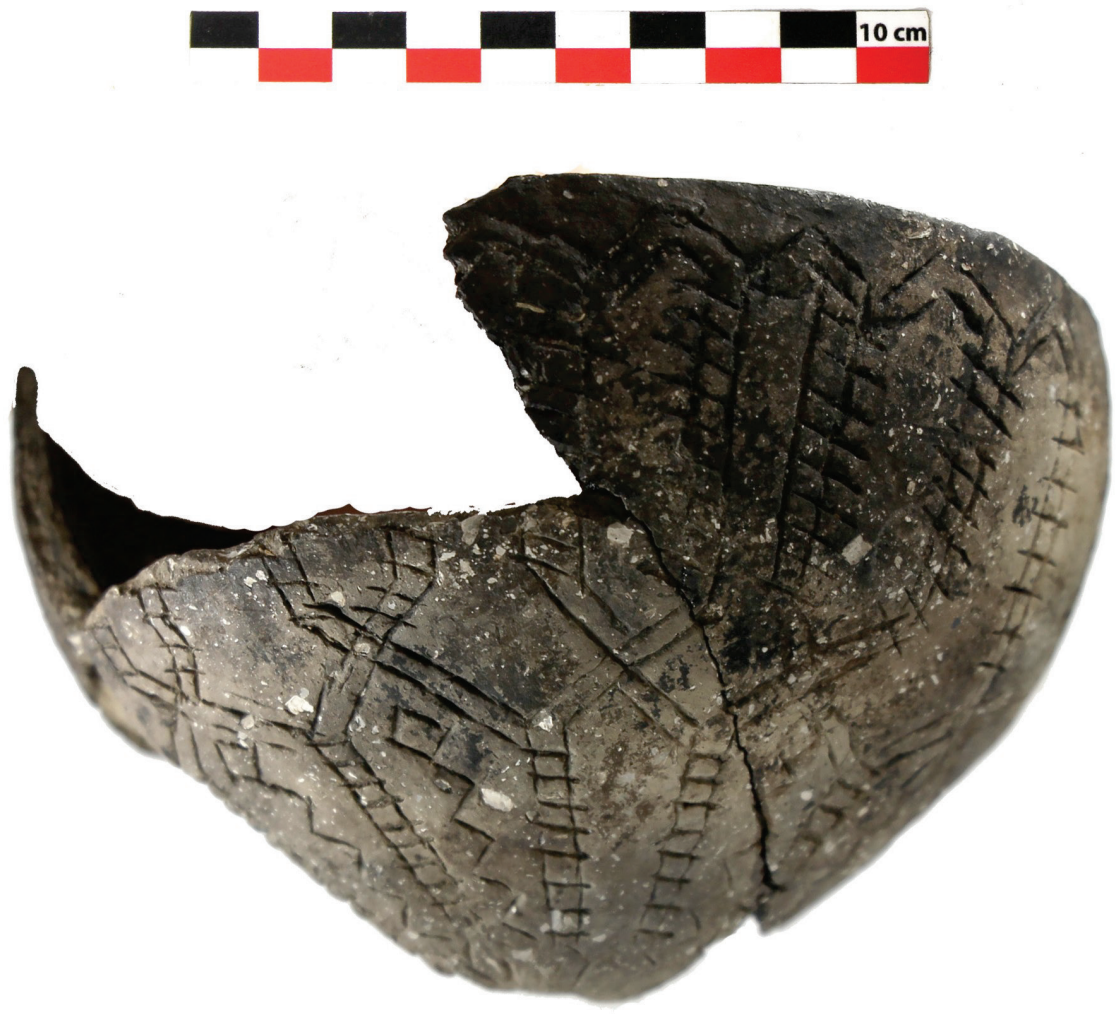

Fig. 8. Vessel found at Serteya II-2 site attributed to the later phase of steppe Eneolithic cultures' influence

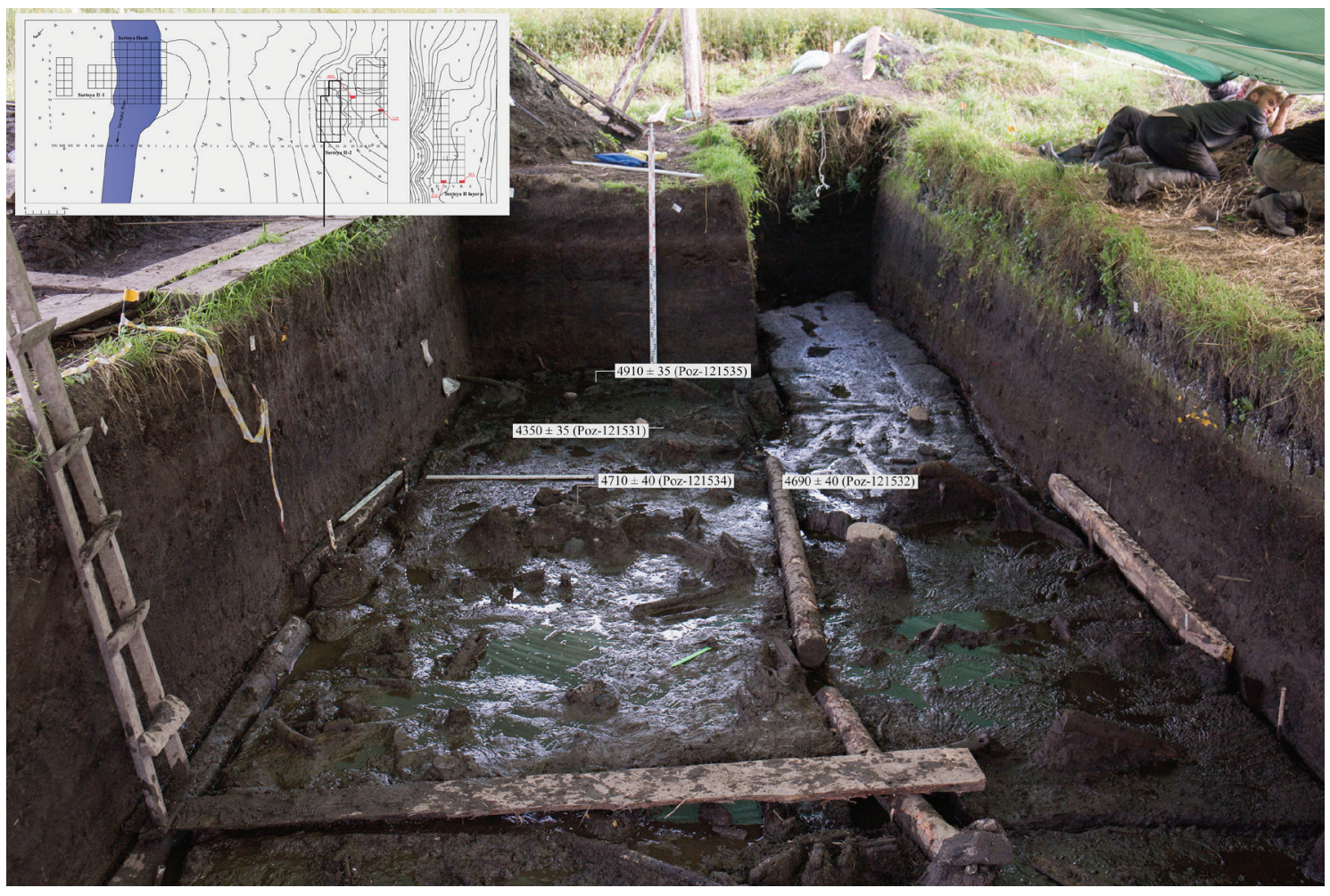

Fig. 9. Upper part of sands with organic mud at Serteya II-2 site with indication of fishing constructions and their radiocarbon date set 


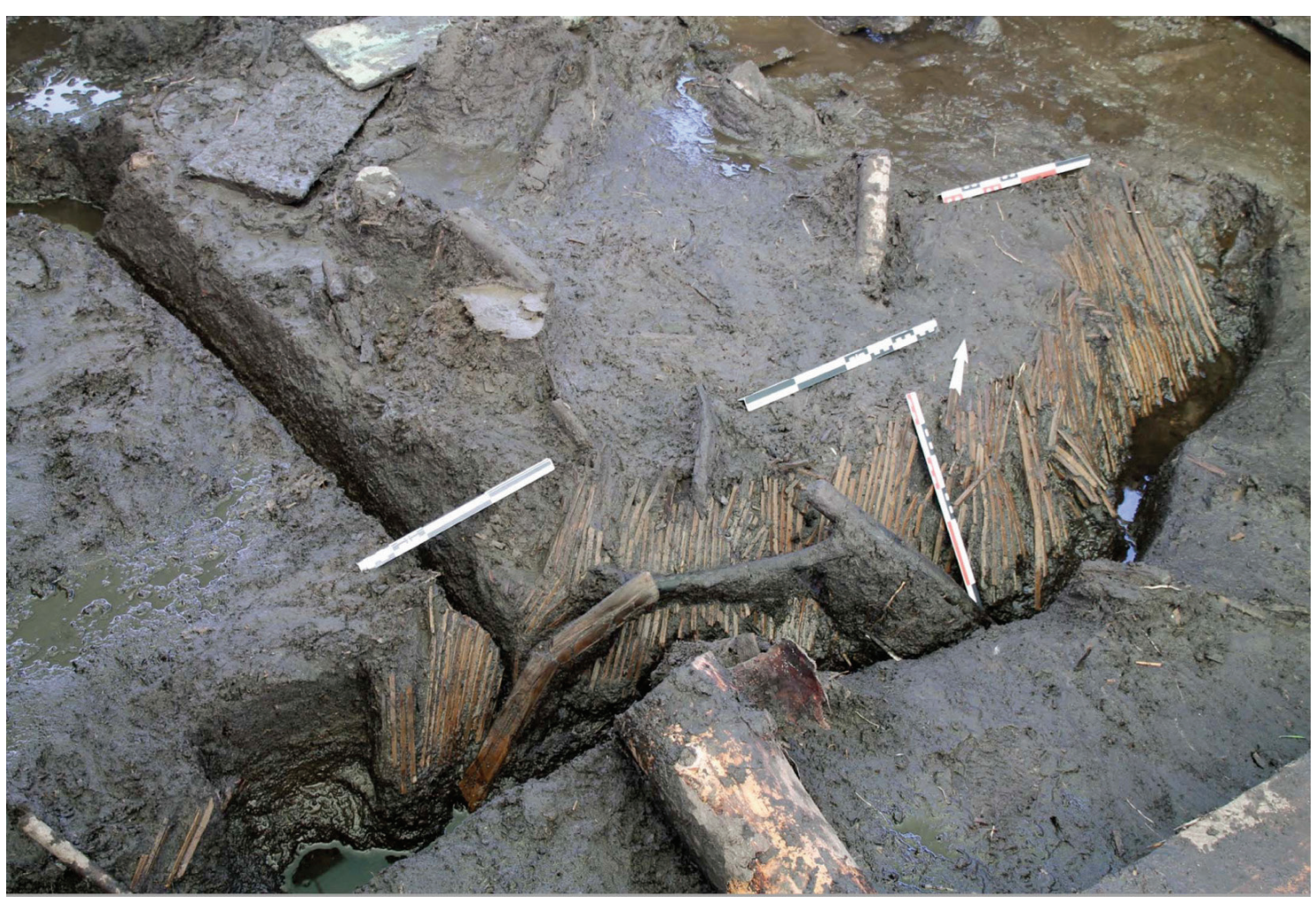

Fig. 10. Fishing construction (Eneolithic) dated to 3633-3372 cal. BC (Serteya II-2 site)

Table 4

Radiocarbon date set of wooden piles, remains of fishing constructions and food crust from the vessel found in Serteya II-1 area (sw. O-T/XII-XIII)

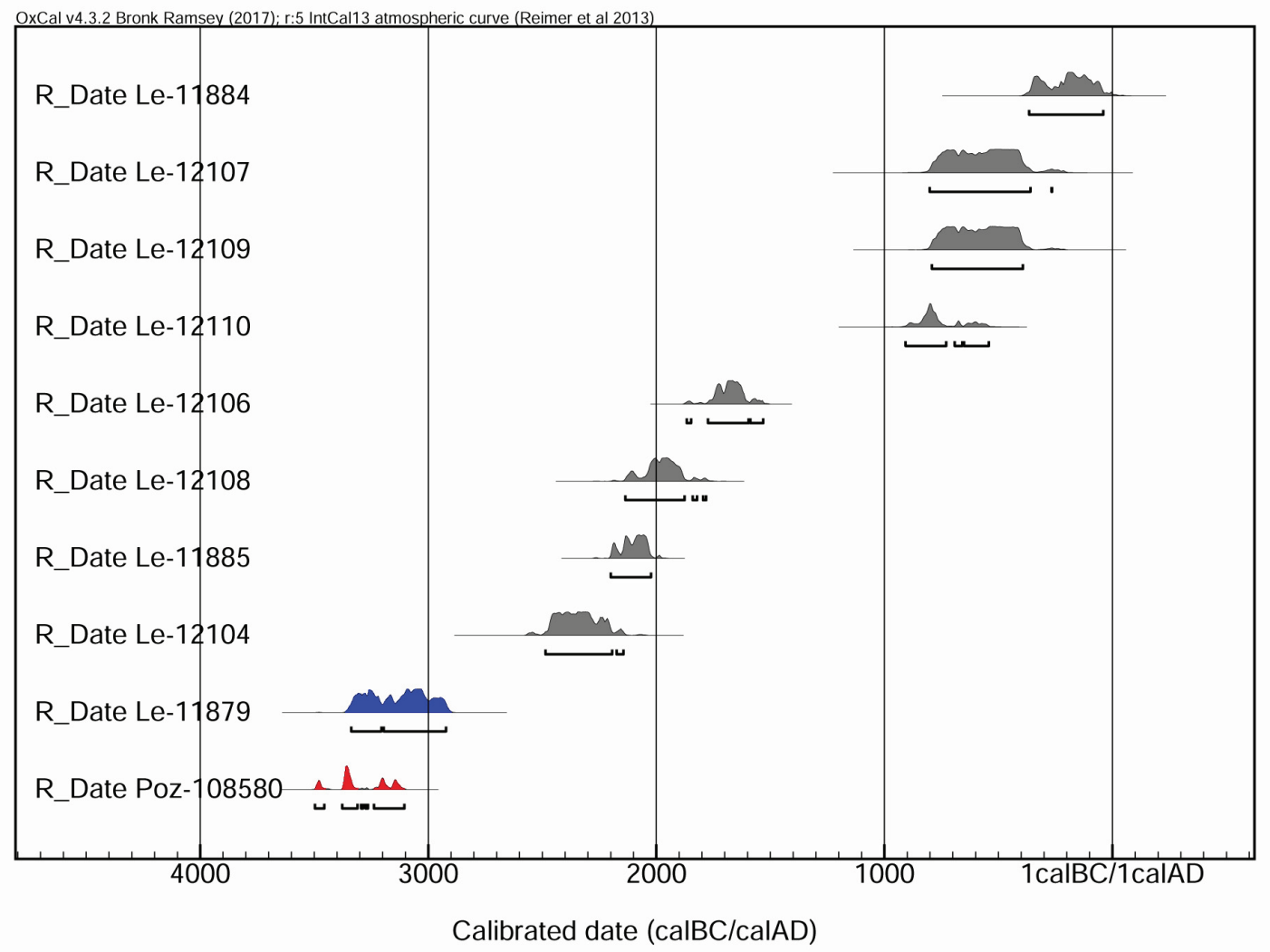

red - food crust, blue - wooden fishing construction, grey - wooden piles and parts of pile-dwellings 
Table 5

Radiocarbon date set of fishing constructions, parts of wooden elements and food crust from vessels attributed to Eneolithic period (Serteya II-2 and Serteya sub - sq. A/V)

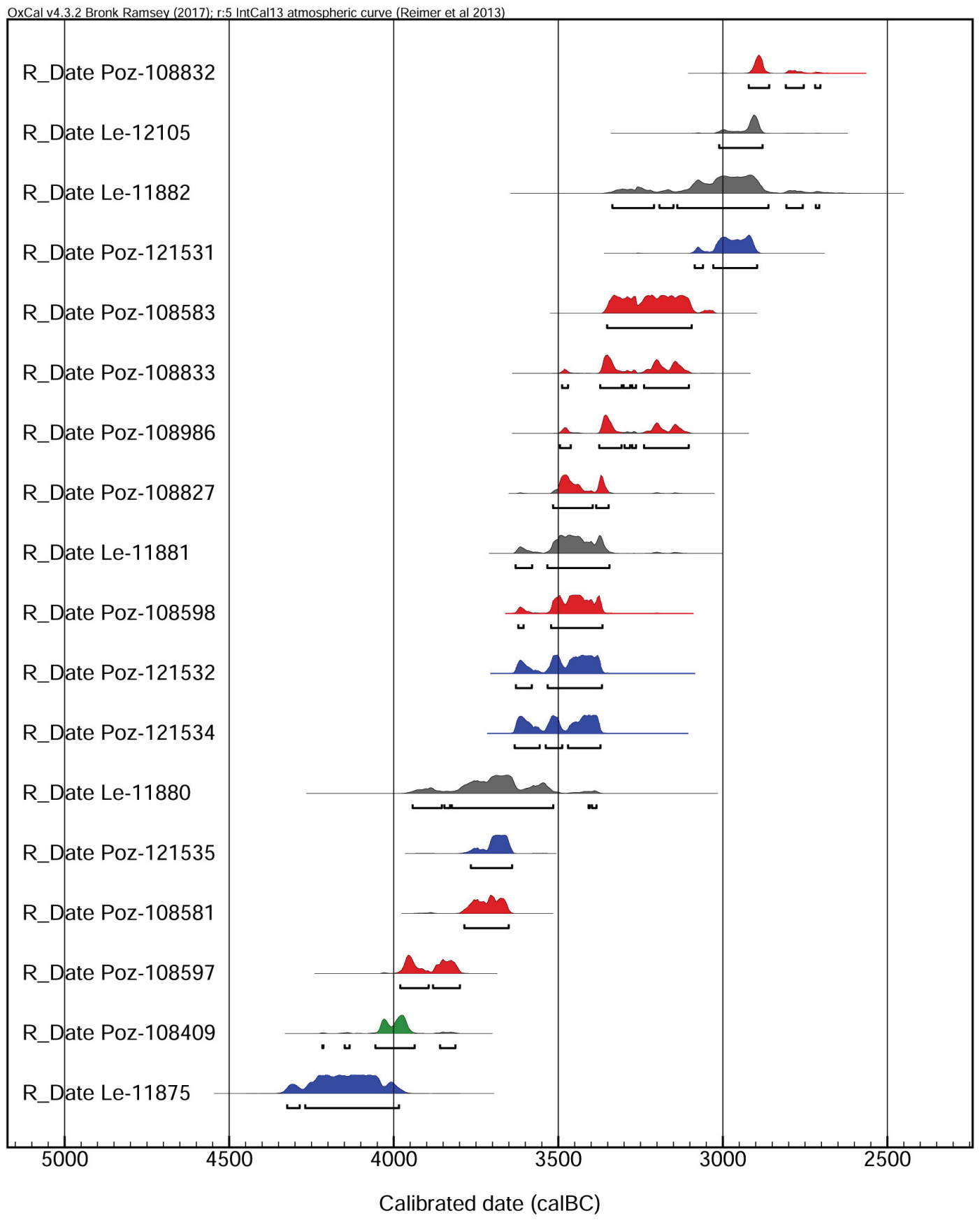

red - food crust, blue - wooden fishing construction, grey - wooden piles and parts of pile-dwellings, green - bone

Episodic appearances of settlement activities on the place of Serteya II-1 at the turn of the $5^{\text {th }}-4^{\text {th }}$ mill. BC are recorded by single radiocarbon dates of wooden piles deposited in brownish gyttja (Table 3, 4, 5). Single finds of remains of fishing structures, stakes and vessels indicate that the site had been used as a fishing spot before the pile-dwelling settlement was established here (Table 4). 


\section{Brown and olive coarse-detritus gyttja (II-2, II-1): Middle Forest Neolithic remains (Zhizhitsa Culture)}

The Zhizhitsa Culture "dwelling" horizon corresponds to the LMAZ (plant macrofossils assemblage zone) IIb (131-115 cm b.g.l.) according to the STII M25 core. The penetration of younger Zhizhitsa Culture finds into the lower layers recorded in various parts of the site (down to $147 \mathrm{~cm} \mathrm{b.g.1.)} \mathrm{may} \mathrm{be} \mathrm{explained} \mathrm{by} \mathrm{the} \mathrm{fact}$ that they were pressed into the lower gyttja layer - into the bottom of the still existing lake (Fig. 7). Furthermore, this can also be attested by the highest number of hydrophytes that were recorded at this level (LMAZ IIa), and the few fish remains along with the presence of moss and charcoals resulting from human activity at the site (Kittel et al. 2020a).

The "dwelling" horizon of the Zhizhitsa Culture comprises a record of more fish bones and water lilies, fewer deep-water plants, a lot of moss, and nutrient-loving herbs (Kittel et al. 2020a). The western part of the site (II-2) is characterised by the absence of traces of flint processing, and the presence of single tools, a relatively large number of arrowheads, and butchering zones (Mazurkevich et al. 2017b), all of which contribute to its significant difference comparing with the main living area of the piledwelling settlement (Serteya IIsub and II-1), where a variety of tools were traced, as well as debitage in the hearth zone. A much smaller number of fish bones was recorded in this area than in the pile-dwelling settlement. A large number of fragments of paddles was found in this area and none were revealed in the eastern dwelling area of the pile settlement. Similar vessels were recorded in both these parts of the site. However, much lower numbers and more fragmented vessels were found in the western part, including also the Serteya II layer $a$ site, where ancient communities might have moved during seasonal flooding.

In the eastern part of the site (Serteya II-1 and Serteya IIsub) were registered the remains of a pile settlement, which date back mainly to the middle and second half of the $3^{\text {rd }}$ mill. BC (Table 1, 2, 3; Figs 1, 5). This part could have been inhabited only during a regression phase at the end of the $4^{\text {th }}$ mill. $\mathrm{BC}$ and later in the $3^{\text {rd }}$. The settlement consisted of several dwellings with rectangular platforms of about $7 \times 4.5$ metres, attached to piles with the aid of ropes and supported from below by "crotch" piles. The basis of the platform consisted of logs of 9-12 $\mathrm{cm}$ in diameter, oriented east-west. Poles of $5-8 \mathrm{~cm}$ in diameter were densely laid on the logs in transverse position. Treated slabs, about $6 \mathrm{~cm}$ thick, were placed above at right angles to the poles. A layer of moss lay above, strewn with coarsegrained sand. A hearth situated on a sandy substratum was formed with big stones laid out in a circle. The walls could have been made of main branches cleaned from lateral branches. Largediameter pile-pillars were installed mainly at the corners of the platform and pairs of smallerdiameter pile-pillars were placed between them along the perimeter (Mazurkevich et al. 2011). Major parts of the buildings not covered by thick sandy layers were destroyed by further water level fluctuations. The level of the ancient bedding surface can be reconstructed based on a dwelling platform that dropped and was not damaged. What mostly survived were central parts of the dwelling platforms covered by several thick layers of sand that served as a hearth platform, and storage/garbage pits, where the majority of artefacts were found. They were deposited within brownish coarse-detritus gyttja. The destruction of sandy platforms may have led to the formation of the sandy brownish coarsedetritus gyttja layer in the bottom of the archaeological stratum (Fig. 5). The thick gyttja layer and muddy sediments below the structures indicate the existence of a lacustrine water body long before the appearance of the pile-dwelling settlement.

\section{Brown coarse-detritus gyttja: later phase of the Zhizhitsa Culture}

The very high concentration of midges and a very distinct peak of charcoals in gyttja deposits recorded at 115 b.g.l. is probably related to a later episode of the Zhizhitsa Culture "horizon" (Kittel et al. 2020a). The date (2566-2462 cal. BC) and depth of the sample dated $(116 \mathrm{~cm})$, coincide with the time of the Zhizhitsa Culture people's activity. A fragment of braid found at the highest level of the Zhizhitsa Culture horizon was dated to $3760 \pm 35 \mathrm{BP}$ (Poz-121530), i.e. 2289-2041 cal. BC - which may indicate the upper chronological border of the Zhizhitsa Culture's existence, which correlates also with dates made for the pile-dwelling settlement in the eastern part of the site (Serteya II-1). It might have been destroyed due to a gradual washing out of the archaeological layer that coincided 
with the reconstructed lowering of the water table within the GSPB at that time.

Under the mud layer, in the brown coarsedetritus gyttja with numerous wood fragments, two almost complete skeletons of young women deposited in non-anatomical order and a small part of a third skeleton were registered. Skeleton bones are distributed at depths from 75 to approximately $118 \mathrm{~cm} \mathrm{b.g.1.} \mathrm{(according} \mathrm{to} \mathrm{the} \mathrm{STII}$ M25 core - see Kittel et al. 2020a). The upper bones of the skeletons were deposited in the upper part of the brown coarse-detritus gyttja with rich wood fragments. At the depth of 105$110 \mathrm{~cm}$ b.g.l. one can trace the horizon to which the skeleton bones are confined, which corresponds to the border of the brown coarse-detritus gyttja and the blackish gyttja layer. Single finds of bones can be traced below - to $115 \mathrm{~cm}$ b.g.l. (Fig. 7). The maximum of moss can be traced at the depth of 95-100 cm b.g.l. (see Kittel et al. 2020a), which could mark the shore zone where taller vegetation cover had not yet been formed.

During excavations, the maximum concentration of wood (poles and branches with diameter from 2 to $6 \mathrm{~cm}$ ) was observed near the skeleton bones. Most skeleton bones were found between these clusters of wood. The bones were located with the centre of gravity facing down, which indicates that the bodies were deposited on an open surface, and after the decay of soft tissues the bones quietly decomposed between the wooden remains (Mazurkevich et al. 2017a). The bones were deposited rather densely, creating a pile that could also testify to this scenario. The bodies might have been put on a sort of "wood platform" or just dumped on a pile of wood. The accumulation of branches was recorded at $c a 110-115 \mathrm{~cm}$ b.g.l. according to the STII M25 core (see Kittel et al. 2020a). A certain contradiction arises between the dating of the wooden remains and the bones. The wooden remains from the accumulation of bones were dated to $3760 \pm 20 \mathrm{BP}$ (Le11161 ), i.e. $2202-2142$ cal. BC. Plant macro fossils from the STII M25 core from $116 \mathrm{~cm}$ b.g.l. are dated to $3967 \pm 33$ BP (MKL-A3979), i.e. 2566-2462 cal. BC (Kittel et al. 2020a) - the level slightly lower than the "burial platform". Bone of the skeleton was dated to $4080 \pm 35 \mathrm{BP}$ (Poz-103947), i.e. 2836-2504 cal. BC (Lorkiewicz et al. in prep.). The wooden branches overlapping the skeleton bones and the lower levels of the wood were dated to $3450 \pm 50 \mathrm{BP}$ (Le-11162), i.e. 1876-1691 cal. BC (Mazurkevich et al. 2017b).
Bones lie above the materials of the Zhizhitsa Culture and chronologically can be attributed to the final stage of its existence. This contradiction can possibly be explained by the fact that the ${ }^{14} \mathrm{C}$ date made for the bones was overestimated due to the specifics of the aquatic diet, which can be verified in further studies. The lower part of the bones' location corresponds to the slow and occasional flooding period, judging by the description of the LMAZ IIc zone (115$101 \mathrm{~cm} \mathrm{b.g.1.),} \mathrm{where} \mathrm{the} \mathrm{presence} \mathrm{of} \mathrm{pioneer}$ vegetation, such as mosses, and the sharp reduction in aquatic plants were recorded. Later this area was covered by constant lake water again based on the description of the overlying zone LMAZ IId (101-84 cm b.g.l.) where more evidence of aquatic vegetation was documented again (Kittel et al. 2020a). Perhaps this can explain the fact that the bones were not taken away by wild animals in the past and preserved almost in-situ - moved only a short distance.

\section{Upper stratum: the later phase}

Episodic appearances of settlement activities at the Serteya II- 1 site in the $2^{\text {nd }}$ mill. BC and Middle Ages are recorded by single radiocarbon dates of wooden piles (Table 3, 4, 5). The lacustrine deposits and deposits formed in the shore zone of the western part (Serteya II-2, Serteya II layer $\alpha$ ) with Neolithic archaeological layers were covered with an overbank sandy and silty organic mud layer, dated after $c a 400 \mathrm{AD}$, as demonstrated by the ${ }^{14} \mathrm{C}$ data of a cow mandible from the border of the muddy brown gyttja and silty organic mud layer in square O26/27 $(1685 \pm 30 \mathrm{BP}$ [Poz-108410], i.e. 335-400 AD). The upper part of brown gyttja may be synchronous with the existence of the Textile Ceramics Culture on the higher part - in the Serteya II layer $\alpha$ area - belonging to the Late Bronze Age of the first half to the middle of the $2^{\text {nd }}$ mill. $\mathrm{BC}$ based on dates obtained for similar complexes in other regions. This period between $c a 1850 \mathrm{BC}$ and $c a 1600 \mathrm{BC}$ is characterised by the natural succession of the lake towards wetland and intensification of slope processes and further flooding after $c a 1500 \mathrm{BC}$ (Kittel et al. 2020a). A hiatus in occupation during 2100 to $1800 \mathrm{cal}$. BC after the termination of the pile-dwelling settlement clearly shows the recovering of the ecosystem and its further evolution without any anthropogenic influence. All the changes that occurred are of natural, probably climatic origin, such as floods caused by unusual snowmelt conditions (Kittel et al. 2020a). 


\section{Discussion}

The western part of the site (Serteya II-2 area) is a multilayer complex where the process of accumulation of depositional units and formation of archaeological layers was much more complicated to understand than in the eastern part, reflecting the peculiarities of palaeolake shore processes and changes in the water regime - lacustrine/fluvial-lacustrine/fluvial, as well as slopeand human-induced. Archaeological layers are included in the sandy sediments and within the lacustrine deposits of the GSPB shore zone (squares Z-S/21-29) and on the slope of the siltysandy kame (layer $\alpha$, sq. B-E/3-15) (Kittel et al. 2018 , in this issue). The different deposits that have been identified here might reflect differences in the processes of their formation. Judging by the distribution of finds and change in sediments deposition, the latter may quite clearly distinguish different cultural and chronological horizons characterised by certain environmental conditions, and their further change. The particularity of the distribution of finds belonging to different cultural horizons allows us to distinguish the main phases of occupation within the coarse-detritus gyttja. The analysis of distribution of individual fragments originating from single reconstructed vessels points to quite different processes of their deposition - e.g. a more intense washing out of archaeological layers containing older vessels ("Eneolithic" and Early Neolithic cultures) that could have been washed away from higher places (Fig. 7). Meanwhile, a more distinct stratigraphic sequence of artefacts can be traced in the northern part of the Serteya II-2 area, where they might have been covered rather quickly by lacustrine sediments.

Different "dwelling" horizons and horizons with concentrations of specific artefacts can be reconstructed for Forest Neolithic cultures. The horizon of $c a 115 \mathrm{~cm} \mathrm{b.g.l.} \mathrm{(Zhizhitsa} \mathrm{Culture)}$ and $c a 145-147 \mathrm{~cm} \mathrm{b.g.l.} \mathrm{(Usviaty} \mathrm{Culture)} \mathrm{ac-}$ cording to the STII M25 core can be recognised as a surface that was temporally (or seasonally) drained and inhabited/used by people. This surface was formed on the area where lacustrine bottom sediments were drying during the lowering of the water table and that is recognised as comprising levels within the gyttja layer that was slightly flooded and waterlogged.

The distribution of wooden artefacts at the Serteya II-2 site corresponds to two levels of distribution of pottery of the Zhizhitsa Culture ( $\mathrm{ca}$ $122-132 \mathrm{~cm}$ b.g.l.) and the Usviaty Culture ( $\mathrm{ca}$
$145 \mathrm{~cm}$ b.g.l.). The distribution of micro-sherds (small, $3 \times 5 \mathrm{~cm}$, usually washed-out fragments) of clay vessels indicates periods of erosion of cultural remains. Major accumulation of micro-fragments corresponds to the boundary of overbank organic mud and brown gyttja layers with wood remains, as well as to the layer of brown-olive gyttja. The lowest number of micro-fragments was attested in the lower part of sandy gyttja. The highest amount of charcoal at $115-116 \mathrm{~cm}$ b.g.l. coincides with the reconstructed terrain surface used by Zhizhitsa Culture communities. The next, smaller peaks of charcoal can be correlated with the activity of various cultures $-123 \mathrm{~cm}$ b.g.l. the time of the Zhizhitsa Culture, at 140 and $145 \mathrm{~cm}$ - the Usvyaty Culture, at $150 \mathrm{~cm}$ - possibly corresponds to the Eneolithic cultures episode. Periods of living activity might have led to a reduction in alder as a plant growing in the nearshore zone. This is especially clearly visible during the existence of the Zhizhitsa Culture settlement here, when alder was the main fuel material, based on the analysis of charcoal from the hearths of the pile settlement (Aleksandrovsky 2014; Kittel et al. 2020b).

Palaeolake water level fluctuations strongly influenced the human settlements - the piledwellings were erected during the phase of (almost seasonal) water horizon decrease in the period of the rebuilding of an ecological niche that was forced by environmental changes in the transition from the Atlantic to the Subboreal. The results of palaeoecological study based on the complex analysis of the lacustrine deposits from the western part of the site shows the main palaeolake water table changes and its variable fluctuations during ca 4.3-1.6 ka BC. The dynamic geomorphological system (changeably: lacustrine or swampy and fluvial) strongly influenced the lifestyle and the form of adaptation to ecological conditions that might have been reflected in the creation of pile-dwelling settlements. The settlement survived for numerous seasons before being flooded again (Mazurkevich, Dolbunova 2011; Mazurkevich et al. 2011; Kul'kova et al. 2015a, b). A temporary increase in the lake water level was recorded during the $4.2 \mathrm{ka} \mathrm{BP}$ event. After that, a drop in the lake water level occurred, and later only seasonal flooding resulted from spring thawing (Kittel et al. 2020a). The lacustrine accumulation was replaced by fluvial overbank deposition after $1650 \mathrm{BC}$ (Kittel et al. 2020a) or even in the Medieval period (Kittel et al. 2020b). 


\section{Conclusions}

Archaeological and geoarchaeological study of the Serteya II site allowed the reconstruction of different zones of inhabitation and household activities. Reconstructed environmental conditions correlate strictly with changes in occupation episodes and succession of archaeological cultures: single lost hunting items within the lacustrine sediments in the Mesolithic were followed by attested shore activity zone during the Early Neolithic (finds of single sherds), single fishing (?) constructions and a dwelling area during the period of the Eneolithic cultures' influence and, finally, a vast shore part with a pile-dwelling settlement and other types of constructions and butchering zones. All zones were probably in use during the lifetime of the pile-dwelling Serteya II site in the $3^{\text {rd }}$ mill. BC (Zhizhitsa Culture).

The most intense human activity at the Serteya II-2 site shore area was recorded between 4150 and 3250 cal. BC, when the water table was relatively high and stable, and the eastern part of the site (Serteya II-1) was covered by water. Simultaneously, a significant impact of hunter-fishergatherer communities on the lake water eutrophication was recorded. Later, the pile-dwellings at Serteya II-1 existed in the period of a falling lake water level with seasonal fluctuations. The archaeological context, as well as palaeoecological data, suggests the presence of short-term episodes of drying allowing the pile-dwelling settlement to exist on a dried lake bottom or a post-lake plain.

The surface formed by lacustrine sediments with thin vegetation cover served as a dwelling horizon during the Forest Neolithic and probably Eneolithic time. This particularity, as well as a very dynamic local hydrological system, influenced a lot the formation of archaeological layers and further distribution of finds. Some of the artefacts penetrated into lower older layers (also due to drying cracks), whereas the synchronous layer, if accumulated, must have been washed away during seasonal (mostly spring) flooding. Most artefacts were recorded in the pile-dwelling area, within sandy layers of hearth platforms or household pits. This can explain the absence of complete vessel forms, macro-remains and debitage in the surrounding layer, which was partly washed away. By contrast, the increase in definite categories of macro-remains in the STII M25 core such as moss, charcoal and fish bones in this particular context correlates strictly with horizons of human activity.
Changes in the ecological conditions were recognised for the shore zone area that was occupied and used temporally by hunter-fishergatherer communities of different archaeological cultures. Settlement densities depended a lot on climate and vegetation changes (Kittel et al. 2018, 2020a). The environmental conditions of the Serteya II site seem to have been very attractive especially for Late Forest Neolithic communities - in regression phases, due to a high level of landscape geo- and biodiversity with small lakes, rivers and fertile hydrogenic and semihydrogenic soils.

The palaeoenvironmental research contributes greatly to broadening the knowledge of the functioning and transformation of the natural environment in the Neolithic during the period of global climate changes $c a 3900$ and $2200 \mathrm{cal}$. BC and its influence on cultural choices. The latter can explain significant retarding of transition from a hunter-fisher-gatherer economy into a productive one though the clear influences of Globular Amphora Culture that can be traced in pottery décor, forms, and particular amber ornaments. The steppe "nomad" cultures' did not influence local inhabitants, and disappeared without leaving any significant traces in local material culture, and were then succeeded by the next culture. The last "steppe" wave, possibly connected with the Sredny Stog Culture, might have contributed to the formation of the Usviaty Culture.

\section{Acknowledgments}

Archaeological research was supported by a grant of the Russian Science Foundation (project "Lacustrine sites of the $4^{\text {th }}-3^{\text {rd }}$ mill. BC - the origins and development of pile-dwelling settlements phenomenon in NW Russia” №19-7800009). The archaeological mission 2 NOR was supported by the French Ministry for Europe and Foreign Affairs. The palaeoecological research at Serteya II site is financed by grants from the "National Science Centre, Poland" based on decision No. 2017/25/B/HS3/00274. We would like to thank Dr Caroline Heitz and Dr Elena Pranckenaite for their valuable comments on this paper. 


\section{References}

Aleksandrovsky A. 2014. Natural-scientific researches of archaeological sites in Serteysky microregion: soils and anthracology. In: A. Mazurkevich, M. Polkovnikova, E. Dolbunova (eds) Archaeology of lake settlements IV-II mill. $B C$ : chronology of cultures, environment and palaeoclimatic rtyhms. Saint-Petersburg: 138146.

Bronk Ramsey C. 2009. Bayesian analysis of radiocarbon dates. Radiocarbon 51(1): 337-360.

Chernyhk E.N., Avilova L.I., Orlovskaya L.B. 2000. Metallurgicheskie provincii $i$ radiouglerodnaya hronologiya. Moscow.

Kittel P., Mazurkevich A., Dolbunova E., Kazakov E., Mroczkowska A., Pavlovskaia E., Piech W., Płóciennik M., Sikora J., Teltevskaya Y., Wieckowska-Lüth M. 2018. Palaeoenvironmental reconstructions for the Neolithic piledwelling Serteya II site case study, Western Russia. Acta Geographica Lodziensia 107: 191213.

Kittel P., Mazurkevich A., Wieckowska-Lüth M., Pawłowski D., Dolbunova E., Gauthier E., Krąpiec M., Maigrot Y., Danger M., Mroczkowska A., Okupny D., Płóciennik M., Szmańda J., Thiebaut E., Słowiński M. 2020a (submitted). On the border between land and water: the environmental conditions of the Neolithic occupation from 4.3 until $1.6 \mathrm{ka} \mathrm{BC}$ at Serteya, Western Russia. Geoarchaeology -An Interdisciplinary Journal.

Kittel P., Mazurkevich A., Alexandrovskiy A., Dolbunova E., Krupski M., Szmańda J., Stachowicz-Rybka R., Cywa K., Mroczkowska A., Okupny D. 2020b. Lacustrine, fluvial and slope deposits in the wetland shore area in Serteya, Western Russia. Acta Geographica Lodziensia 110: 103-124.

Kul'kova M.A., Mazurkevich A.N., Dolbunova E.V., Lozovsky V.M. 2015a. The 8200 cal BP climate event and the spread of the Neolithic in Eastern Europe. Documenta Praehistorica 42: 77-92.

Kul'kova M.A., Mazurkevich A., Gerasimov D. 2015 b. Stone Age archaeological sites and environmental changes during the Holocene in the NW region of Russia. In: J. Harff, G. Bailey, F. Lüth (eds) Geology and Archaeology: Submerged Landscapes of the Continental Shelf. Geological Society, London: 27-50.

Lorkiewicz W., Borówka P., Shirobokov I., Mazurkevich A., Dolbunova E., Wieckowska-Lüth M., Płóciennik M., Kittel P. (in prep.). Human remains from the wet land in Western Dvina Lakeland: anthropological, genetic, cultural, and environmental context.
Mazurkevich A., Dolbunova E. 2011. Underwater Investigations in Northwest Russia: lacustrine archaeology of Neolithic pile dwellings. In: J. Benjamin, C. Bonsall, C. Pickard, A. Fischer (eds) Submerged Prehistory. Oxbow Books, Oxford: 158-172.

Mazurkevich A., Dolbunova E. 2015. The oldest pottery in hunter-gatherer communities and models of Neolithisation of Eastern Europe. Documenta Praehistorica 42: 13-66.

Mazurkevich A.N., Dolbunova E.V., Kulkova M.A., Regert M., Mazuy A. 2014. Dynamics of cultural changes - local traditions and imports in ceramic complexes of pile-dwellings (site Serteya II, Smolensky region). In: A.N. Mazurkevich, M.E. Polkovnikova, E.V. Dolbunova (eds) Archaeology of lake settlements IV-II mill. $B C$ : chronology of cultures, environment, and palaeoclimatic rhythms. Materials of international conference dedicated the semi-centennial anniversary of the researches of lake dwellings in North-Western Russia, Saint-Petersburg, 1315 November 2014. The State Hermitage Museum, Saint-Petersburg: 242-247.

Mazurkevich A.N., Dolbunova E.V., Maigrot Y., Hookk D. 2011. Results of underwater excavations of Serteya II and research of piledwellings in Northwest Russia. Archaeologia Baltica 14: 47-64.

Mazurkevich A.N., Kulkova M.A., Dolbunova E.V. (eds) 2016. Radiocarbon Neolithic chronology of Eastern Europe in the VII-III millennium BC. Smolensk, Svitok.

Mazurkevich A.N., Maigrot Y., Dolbunova E.V., Polkovnikova M.E., Shirobokov I.G. 2017a. Issledovanija neoliticheskogo pamyatnika Serteya II. Arheologicheskii sbornik Gosudarstvennogo Ermitaja 41:108-112.

Mazurkevich A., Dolbunova E., Kittel P., Fassbender J., Maigrot Y., Mroczkowska A., Płóciennik M., Sikora J., Słowiński M., Sablin M., Shirobokov I. 2017b. Multi-disciplinary research on the Neolithic pile-dwelling Serteya II site (Western Russia) and the landscape reconstruction. In: A. Marciniak-Kajzer, A. Andrzejewski, A. Golański, S. Rzepecki (eds) Nie tylko krzemienie. Not only flints. Instytut Archeologii Uniwersytetu Łódzkiego, Łódzka Fundacja Badań Naukowych, Stowarzyszenie Naukowe Archeologów Polskich Oddział w Łodzi, Łódź: 103-128.

Miklyaev A.M. 1995. Kamennyi-zheleznyi vek v mezhdurech'e Zapadnoi Dviny i Lovati. Peterburgskii Arheologicheskii Vestnik 9: 5-39.

Morgunova N.L., Vybornov A.A., Kovalyuhk N.N., Skripkin V.V. 2010. Hronologicheskoe sootnoshenie eneoliticheskih kul'tur Volgo-Ural'skogo regiona $\mathrm{v}$ svete radiouglerodnogo datirovaniya. Rossiskaya archaeologija 4: 18-27. 
Reimer P.J., Baillie M.G.L., Bard E., Bayliss A., Beck J.W., Blackwell P.G., Bronk Ramsey C., Buck C.E., Burr G.S., Edwards R.L., Friedrich M., Grootes P.M., Guilderson T.P., Hajdas I., Heaton T.J., Hogg A.G., Hughen K.A., Kaiser K.F., Kromer B., McCormac F.G., Manning S.W., Reimer R.W., Richards D.A., Southon J.R., Talamo S., Turney C.S.M., van Der Plicht J., Weyhenmeyer C.E. 2009. IntCal09 and Marine09 radiocarbon age calibration curves, 0-
50,000 years cal BP. Radiocarbon 51: 11111150

Szmyt M. 2010. Between West and East. People of the Globular Amphora culture in Eastern Europe: 2950-2350 BC. Baltic-Pontic studies. Volume 8.

Zaltsman E.B. 2019. Vostochnaya gruppa primorskoy kultury. Analiz materialov poselencheskih kompleksov. Moscow. 